\title{
The Plurality of Evolutionary Worldviews
}

\author{
Nathalie Gontier ${ }^{1}$
}

Received: 3 March 2021 / Accepted: 17 March 2021/Published online: 13 April 2021

(C) The Author(s), under exclusive licence to Springer Nature B.V. 2021

\begin{abstract}
Evolutionary biologists, evolutionary epistemologists, and biosemioticians have demonstrated that organisms not merely adapt to an external world, but that they actively construct their environmental, sociocultural, and cognitive niches. Denis Noble demonstrates that such is no different for those organisms that engage in science, and he lays bare several crucial assumptions that define the scientific dogmas and practices of evolutionary biology.
\end{abstract}

Keywords Biological relativity $\cdot$ Natural genetic engineering $\cdot$ Modern synthesis · Extended synthesis · Applied evolutionary epistemology

Evolutionary biologists (Gould and Lewontin 1979; Lewontin 1983), evolutionary epistemologists (Gontier and Bradie 2017; Wuketits 2006; von Glasersfeld 1995), and biosemioticians (von Uexküll 1937) have demonstrated that organisms not merely adapt to an external world, but that they actively construct their environmental (OdlingSmee 1988), sociocultural (Laland et al. 1995), and cognitive niches (von Glasersfeld 1995; Magnani 2017). In this eloquently written paper, and thereby building upon von Uexküll's (1937) concept of Umwelt, Denis Noble demonstrates that such is no different for those organisms that engage in science, and more specifically, for those scientists concerned with delineating the scientific dogmas and practices of evolutionary biology. Noble thereby touches upon important debates on the politics of science and the conscious as well as often subconscious role that language and metaphor (Lakoff and Johnson 1980) play in the development of scientific worldviews. This recalls the work of philosophers such as Ludwig Wittgenstein (1953), Thomas Kuhn (1962), and Michel Foucault (1966), who have long demonstrated that beyond data and facts, language games, scientific practices, and regimes of power underlie the scientific discourse of what is defined as normal science, truth and falsehood. Together, these

Nathalie Gontier

nlgontier@ciencias@ulisboa.pt

1 Applied Evolutionary Epistemology Lab \& Centro de Filosofia das Ciências, Departamento de História e Filosofia das Ciências, Faculdade de Ciências, Universidade de Lisboa, 1749-016 Lisbon, Portugal 
phenomena underlie the formation of a scientific niche that defines the Umwelt of scientists, and it provides both a territory and a road map that comes with an entire code of conduct on what ideas to accept and reject, what phenomena to investigate and ignore, and which methods and tools to apply in the process.

In congruence with these Umwelts, the multi-faceted school of evolutionary biology has brought forth a myriad of evolutionary worldviews. When writing his Origin, for example, Charles Darwin (1859) relied on Malthus' (1798) economical work on population growth. Parallels have also long been drawn between his ideas on selection and Adam Smith's (1776) invisible hand metaphor that founded the latter's free-market ideals. And interpretations of natural selection have led to the idea that selection results in the "survival of the fittest" (Spencer 1864: 444), or that it supports the idea that nature is "red in tooth and claw". This phrase is taken from canto 56 of Alfred L. Tennyson's poem (Tennyson 1850) that was actually written nine years before the publication of Darwin's work, and that at the time was more a response to Robert Chambers' (1844) work on the Vestiges of Creation where the transmutation of species had already been discussed. Nonetheless, the phrase is often used as an illustration of how selection operates.

The Modern Synthesis continues this association with liberal and individualistic discourse and this is one of the reasons why it has, following Darwin, emphasized that the organism is the unit of selection (Mayr 1963), and why it has subsequently experienced so much difficulty to even within its own animal-focused science, accept the possibility of altruism (Trivers 1971) or parental investment and sexual selection (Trivers 1972), as well as kin (Hamilton 1964a, 1964b, 1964c), group (WynneEdwards 1962, 1986; DS Wilson and Sober 1994), or multilevel selection (DS Wilson and Sober 1994; Wilson and Wilson 2008; Okasha 2006). In fact, the idea of group selection was only able to integrate recently, and it did so by considering the group as a single (super)organism (DS Wilson and Sober 1989).

As already argued elsewhere (Gontier 2016), this language of combat and the glorification of individualism that associates with the Neodarwinian worldview is also one of the reasons why it has been so difficult for both the paradigm and its adherents to accept the important insights that come from symbiology (Margulis 1998). Just because symbiologists introduce a more interactional discourse when they study mutual and commensal, but also parasitic (van Beneden 1873) interactions amongst organisms that belong to different species, they have been associated if not accused of propagating socialist, communitarian, or communist thought. Consequently, while an ant colony might just qualify as a superorganism, recognizing "individuality," "agency," or "system properties" in macroevolutionary phenomena such as holobionts (Margulis 1998; Guerrero et al. 2013) or earth (Hutton 1788; Lovelock and Margulis 1974) has for many gone too far.

On the other side of the hierarchy, the microevolutionary oriented Neo-Darwinian school that developed after the founding of the Synthesis has dethroned the organism, as well as the man of the Enlightenment, as the "progressive" unit of selection that natural history scholars had proclaimed it to be. Instead, both were replaced with "selfish genes" (Dawkins 1976, 1982) that ride disenchanted, post-modern "vehicles," and such has come to associate with a lobbying for "militant atheism".

Now there have most certainly been scholars such as Kropotkin (1902) that understood the law of mutual aid as an alternative to the "gladiator show," as there have been 
eugenicists such as Fisher (1930) that saw in natural selection a justification for class differentiation and sterilization programs. There have also been sympathizers of Marxism such as Gould and Lewontin (1979) and Levins and Lewontin (1985) that have in association pleaded for a more "dialectical biology". And there have been those that find joy in their affiliation with the biological world such as E.O. Wilson (1984). It thus appears inevitable that evolutionary thought, as a human science, has developed by looking for a mirror in nature of human society. Such is no different for the field of ecology, that commenced by investigating the "industry" (Harting 1862) and "household" or "economy" (Haeckel 1866) of animals, and how their "societies" too are characterized by a "division of labor" and a "distribution of goods" (Egerton 2015). Even van Beneden (1875) developed his ideas on nutritional symbiosis by analogy with how messmates (commenseaux) share their food.

Noble's work demonstrates that genetic trait theories have also strongly depended upon informational and computational jargon (Shannon and Weaver 1949). It is the adoption of an information metaphor that enabled Dawkins (1976) to understand genes as software or as replicating informational codes, and organisms as hardware or programmed vehicles that obey algorithmic rules of conduct (Dawkins 1976; Maynard Smith 2000). It is the adoption of communication theory that enables the central dogma of molecular genetics to proclaim that information "flows", and that it does so from DNA to RNA to proteins, where a series of "messages" become "decoded", "transcribed," and "translated", and where from the 1940s onward, an army of war veterans return to science and commence to unravel "life's hidden secrets" as they had done so before, with the secret intelligence they were able to intercept from their enemies.

The problem with this information narrative is that there is hardly ever such a thing as stand-alone, factual, or objective information that is just broadcasted out there, and ready to be intercepted. Rather, for something to have information value, that something needs to be observed, recognized, communicated, produced, understood, or otherwise interpreted, and any of this always involves a construction. This has long been recognized by evolutionary epistemolgists (von Glasersfeld 1995; Wuketits 2006) and biosemioticians (Wheeler 2020) alike, both of which were thereby inspired by Wiener's (1948) feedback loop that linked a "system's" "output" back onto its "input". That feedback helped pave the way for recognizing downward causation (Campbell 1974b) going, for example, from cultural systems to individual organismal members; and it helped recognize autopoiesis in cognitive agents (Maturana and Varela 1980). In hindsight, such constructivism was even present in behaviorist schools of thought (Skinner 1981) where the habit-to-instinct idea defended by early ethologists (Lorenz 1941, 1958, 1977; Tinbergen 1963) and evolutionary epistemologists (Campbell 1974a; Popper 1963), can be compared to Waddington's (1942) canalization in epigenetic landscapes. And this resurrection of neo-Lamarckian and epigenetic (Ho and Saunders 1979) ideas of inheritance in turn got countered again by gene and population genetic views endorsed by sociobiologists (Wilson 1975).

Noble shows that constructivism has also entered molecular genetics and biochemistry where the important work of Barbara McClintock (1950) and James Shapiro $(2011,2017)$ is demonstrating the genome-wide capacity for "natural genetic engineering". There is a feedback loop that turns the genome onto itself, and such implies a form of reflection from the system unto its parts. Such neither occurs in a 
narcist nor selfish way, but in the form of repair, adjustment, and expansion. Natural genetic engineering implies that there exists knowledge or semiosis from a molecular level onward, and this idea again finds roots in evolutionary epistemology (Campbell 1974a; Hahlweg and Hooker 1989) and biosemiotics (Kull et al. 2011; Sharov and Vehkavaara 2015; Sebeok 1994). As disciplines, they thereby go back to the founding of pragmatism (James 1907, 1909), that alternatively is known by the name of relativism, where scholars first start the scientific study of worldview formation and of worldview pluralism (Gontier and Bradie 2017; Gontier 2018). And such, at last, feeds back into Noble's (2012) principle of biological relativity that incentivizes us to recognize evolution as the outcome of a myriad of mechanisms and processes that beyond reductionist and "one-way" causal views require a "nested view of organization", which is a view that links to hierarchy theory (Pattee 1973; Simon 1962; Tëmkin and Eldredge 2015; Gontier 2018) and with which I most certainly and wholeheartedly agree.

Acknowledgements Cordial thanks to Yogi Hale Hendlin and Alexei Sharov for inviting me to contribute this comment.

Funding Written with the financial support of the Faculdade de Ciências da Universidade de Lisboa (Faculty of Science of the University of Lisbon) and FCT, Fundação para a Ciência e a Tecnologia (the Portuguese Foundation for Science and Technology), Grant ID DL57/2016/CP1479/CT0066 and Project IDs: UID/FIL/00678/2019 and UIDB/00678/2020.

\section{Declarations}

Conflict of Interest None.

\section{References}

Campbell, D. T. (1974a). Evolutionary epistemology. In P. A. Schlipp (Ed.), The philosophy of Karl Popper (Vol. I, pp. 413-459). Chicago: La Salle.

Campbell, D. T. (1974b). Downward causation in hierarchically organized biological systems. In F. J. Ayala \& T. Dobzhansky (Eds.), Studies in the philosophy of biology: Reduction and related problems (pp. 179186). New York: MacMillan Publishing Company.

Chambers, R. (1844) Vestiges of the natural history of creation. London: W and R Chambers.

Wilson, D. S., \& Sober, E. (1989). Reviving the superorganism. Journal of Theoretical Biology, 136(3), 337356.

Darwin, C. (1859). On the origin of species. London: John Murray.

Dawkins, R. (1976). The selfish gene. Oxford: Oxford University Press.

Dawkins, R. (1982). Replicators and vehicles. In N. R. Brandon \& R. M. Burian (Eds.), Genes, organisms, populations (pp. 161-179). Cambridge: MIT Press.

Egerton, F. N. (2015). History of ecological sciences, part 52: Symbiosis studies. Bulletin of the Ecological Society of America, 96, 80-139.

Fisher, R. (1930). The genetical theory of natural selection. Oxford: Clarendon Press.

Foucault, M. (1966). Les mots et les choses. Paris: Editions Gallimard.

von Glasersfeld, E. (1995). Radical constructivism. Bristol: The Palmer Press.

Gontier, N., \& Bradie, M. (2017). Acquiring knowledge on species-specific biorealities: The applied evolutionary epistemological approach. In R. Joyce (Ed.), The Routledge handbook of evolution and philosophy (pp. 136-152). London: Routledge. 
Gontier, N. (2016). Symbiosis, history of. In R. L. Kliman (Ed.), Encyclopedia of evolutionary biology (pp. 272-281). Oxford: Academic Press.

Gontier, N. (2018). On how epistemology and ontology converge through evolution: The applied evolutionary epistemological approach. In S. Wuppuluri \& F. A. Doria (Eds.), The map and the territory (pp. 533569). Cham: Springer.

Gould, S. J., \& Lewontin, R. C. (1979). The spandrels of san Marco and the panglossian paradigm: A critique of the adaptationist programme. Proceedings of the Royal Society B: Biological Sciences, 205(1161), 581-598.

Guerrero, R., Margulis, L., \& Berlanga, M. (2013). Symbiogenesis: The holobiont as a unit of evolution. International Microbiology, 16(3), 133-143.

Haeckel, E. (1866). Generelle Morphologie der Organismen: Allgemeine Grundzüge der organischen Formen-Wissenschaft, mechanisch begründet durch die von Charles Darwin reformirte DescendenzTheorie (Vol. 2). Berlin: Georg Reimer.

Hahlweg, K., \& Hooker, C. (Eds.). (1989). Issues in evolutionary epistemology. New York: State University of New York Press.

Hamilton, W. D. (1964a). The genetical evolution of social behavior I. Journal of Theoretical Biology, 7(1), $1-16$.

Hamilton, W. D. (1964b). The genetical evolution of social behavior II. Journal of Theoretical Biology, 7(1), $17-52$.

Hamilton, W. D. (1964c). The evolution of social behavior. Journal of Theoretical Biology, 1, 295-311.

Harting, P. (1862). De bouwkunst der dieren: Een boek voor allen, die de natuur liefhebben. Groningen: Erven C.M. van Bolhuis Hoitsema.

Ho, M. W., \& Saunders, P. T. (1979). Beyond neo-Darwinism: An epigenetic approach to evolution. Journal of Theoretical Biology, 78, 573-591.

Hutton, J. (1788). Theory of the earth: Or an investigation of the laws observable in the composition, dissolution, and restoration of land upon the globe. Transactions of the Royal Society of Edinburgh, 1(2), 209-304.

James, W. (1907). Pragmatism: A new name for some old ways of thinking. New York: Longmans, Green and Co..

James, W. (1909). A pluralistic universe. New York: Longmans, Green and Co..

Kropotkin, P. (1902). Mutual aid: A factor of evolution. New York: McClure Phillips a Co..

Kuhn, T. (1962). The structure of scientific revolutions. Chicago: Chicago University Press.

Kull, K., Emmeche, C., \& Favareau, D. (2011). Biosemiotic research questions. In C. Emmeche \& K. Kull (Eds.), Towards a semiotic biology (pp. 67-90). London: Imperial College Press.

Lakoff, G., \& Johnson, M. (1980). Metaphors we live by. Chicago: University of Chicago Press.

Laland, K., Kumm, J., \& Feldman, M. (1995). Gene-culture co-evolutionary theory. Current Anthropology, 36(1), 131-146.

Levins, R., \& Lewontin, R. (1985). The dialectical biologist. Cambridge: Harvard University Press.

Lewontin, R. (1983). The organism as subject and object of evolution. Scientia, 188, 65-82.

Lorenz, K. (1941). Kant's Lehre vom Apriorischen im Lichte gegenwärtiger Biologie. Blätter für Deutsche Philosophie, 15, 94-125.

Lorenz, K. (1958). The evolution of behavior. Scientific American, 199(6), 67-78.

Lorenz, K. (1977). Behind the mirror: A search for a natural history of human knowledge. New York: Harcourt Trade Publishers.

Lovelock, J. E., \& Margulis, L. (1974). Atmospheric homeostasis by and for the biosphere: The Gaia hypothesis. Tellus, Series A, Stockholm: International Meteorological Institute, 26(1-2), 2-10.

Magnani, L. (2017). The abductive structure of scientific creativity: An essay on the ecology of cognition. Cham: Springer.

Malthus, T. R. (1798). An essay on the principle of population. London: J. Johnson.

Margulis, L. (1998). The symbiotic planet: A new look at evolution. New York: Basic Books.

Maturana, H. R., \& Varela, F. (1980). Autopoiesis and cognition: The realization of the living. Dordrecht: D. Reidel Company.

Maynard Smith, J. (2000). The concept of information in biology. Philosophy of Science, 67(2), 177-194.

Mayr, E. (1963). Populations, species, and evolution. Belknap: Harvard University Press.

McClintock, B. (1950). The origin and behavior of mutable loci in maize. Proceedings of the national academy of sciences, USA, 36, 344-355.

Noble, D. (2012). A theory of biological relativity. Interface Focus, 2, 55-64.

Odling-Smee, F. J. (1988). Niche constructing phenotypes. In H. Plotkin (Ed.), The role of behavior in evolution (pp. 73-132). Cambridge: MIT Press. 
Okasha, S. (2006). Evolution and the levels of selection. Oxford: Oxford University Press.

Pattee, H. H. (Ed.). (1973). Hierarchy theory: The challenge of complex systems. New York: Braziller.

Popper, K. (1963). Conjectures and refutations. London: Routledge and Kegan and Paul.

Sebeok, T. A. (1994). Signs: An introduction to semiotics. Toronto: University of Toronto Press.

Shannon, C., \& Weaver, W. (1949). The mathematical theory of communication. Chicago: The University of Illinois Press.

Shapiro, J. A. (2017). Biological action in read-write genome evolution. Interface Focus, 7, 20160115.

Shapiro, J. (2011). Evolution: A view from the 21st century. Upper Saddle River: FT Press.

Sharov, A. A., \& Vehkavaara, T. (2015). Protosemiosis: Agency with reduced representation capacity. Biosemiotics, 8(1), 103-123.

Simon, H. A. (1962). The architecture of complexity: Hierarchic systems. Proceedings of the American Philosophical Society, 106, 467-482.

Skinner, B. F. (1981). Selection by consequences. Science, 213, 501-504.

Smith, A. (1776). An inquiry into the nature and causes of the wealth of nations (2 volumes). London: Methuen \& Co., Ltd..

Spencer, H. (1864). Principles of biology (Vol. 1). Edinburgh: Williams and Norgate.

Tëmkin, I., \& Eldredge, N. (2015). Networks and hierarchies: Approaching complexity in evolutionary theory. In E. Serrelli \& N. Gontier (Eds.), Macroevolution (pp. 183-226). Cham: Springer.

Tennyson, L. A. (1850). In memorial a.H.H. London: Edward Moxon.

Tinbergen, N. (1963). On aims and methods of ethology. Zeitschifft für Tierpsychologie, 20, 410-433.

Trivers, R. L. (1971). The evolution of reciprocal altruism. The Quarterly Review of Biology, 46(1), 35-57.

Trivers, R. L. (1972). Parental investment and sexual selection. In B. Campbell (Ed.), Sexual selection and the descent of man (pp. 136-179). Chicago: Aldine.

Uexküll, J. von. (1937). The new concept of Umwelt: A link between science and the humanities. Semiotica, 134 1/4 (2001), 111-23.

Van Beneden, P. J. (1873). Un mot sur la vie sociale des animaux inférieurs. Bulletin de l'Académie Royale de Belgique, 2(36), 779-796.

Van Beneden, P.J. (1875). Les commensaux et les parasites dans le règne animal. Paris : Bibliothèque scientifique internationale.

Waddington, C. H. (1942). Canalization of development and the inheritance of acquired characters. Nature, $150(3811), 563-565$.

Wheeler, W. (2020). Information and meaning. Oxford research encyclopedia of literature. https://oxfordre. com/literature/view/10.1093/acrefore/9780190201098.001.0001/acrefo re-9780190201098-e-969.

Wiener, N. (1948). Cybernetics: Or control and communication in the animal and the machine. Cambridge: MIT Press.

Wilson, D. S., \& Wilson, E. O. (2008). Evolution 'for the good of the group'. American Scientist, 96(5), 380389.

Wilson, D. S., \& Sober, E. (1994). Reintroducing group selection to the human behavioral sciences. Behavioral and Brain Sciences, 17(4), 585-654.

Wilson, E. O. (1984). Biophilia. Cambridge: Harvard University Press.

Wilson, E. O. (1975). Sociobiology: The new synthesis. Cambridge: Harvard University Press.

Wittgenstein, L. (1953). Philosophical investigations. New York: Macmillan Publishing Company.

Wuketits, F. M. (2006). Evolutionary epistemology: The non-adaptationist approach. In N. Gontier, J. P. Van Bendegem, \& D. Aerts (Eds.), Evolutionary epistemology, language and culture (pp. 33-46). Dordrecht: Springer.

Wynne-Edwards, V. C. (1962). Animal dispersion in relation to social behaviour. Edinburgh: Oliver \& Boyd. Wynne-Edwards, V. C. (1986). Evolution through group selection. Oxford: Blackwell.

Publisher's Note Springer Nature remains neutral with regard to jurisdictional claims in published maps and institutional affiliations. 